\title{
Stimulating the Growth of Kefir-isolated Lactic Acid Bacteria using Addition of Crude Flaxseed (Linum usitatissimum L.) Extract
}

\author{
Dong-Hyeon $\mathrm{Kim}^{1 \dagger}$, Dana Jeong ${ }^{1 \dagger}$, Yong-Taek Oh${ }^{1}$, Kwang-Young Song ${ }^{1 *}$, \\ Hong-Seok Kim ${ }^{1}$, Jung-Whan Chon ${ }^{1,2 \dagger}$, Hyunsook Kim ${ }^{3}$, and Kun-Ho Seo ${ }^{1 \dagger}$ \\ ${ }^{1}$ Center for One Health, College of Veterinary Medicine, Konkuk University, Seoul, Korea \\ ${ }^{2}$ National Center for Toxicological Research, US Food and Drug Administration, Jefferson, AR, USA \\ ${ }^{3}$ Dept. of Food \& Nutrition, College of Human Ecology, Hanyang University, Seoul, Korea
}

\begin{abstract}
Linum usitatissimum L. (flaxseed) is emerging as an important functional food ingredient because of its rich contents, namely, $\alpha$-linolenic acid (ALA, omega- 3 fatty acid), lignans, and fiber, which are potentially beneficial for human health. Furthermore, flax or flaxseed oil has also been incorporated as a functional food ingredient into various foods such as milk, dairy products, and meat products. Flaxseed is known to possess antimicrobial activity in vitro and in vivo, but its growth-stimulating effect on lactic acid bacteria is not clear. Hence, the objective of this study was to determine whether crude flaxseed extract stimulated the growth kefir-isolated lactic acid bacteria in vitro. The result of this study showed that Lactobacillus kefiranofaciens DN1, Lactobacillus brevis KCTC3102, Lactobacillus bulgaricus KCTC3635, and Lactobacillus plantarum KCTC3105 treated with $100 \mu \mathrm{L}$ of crude flaxseed extract showed significantly higher growth than the control treated with $100 \mu \mathrm{L}$ of water $(p<0.05)$. Based on the results of this study, crude flaxseed extract could be used as a growth stimulator for lactic acid bacteria in various food applications, including production of milk and dairy products.
\end{abstract}

\section{Keywords}

flaxseed, lactic acid bacteria, kefir, growth stimulator

\section{Introduction}

The Latin name of the flaxseed was Linum usitatissimum L., which means "very useful". And flaxseed was an annual herb and originated from Egypt (Kaithwas et al., 2011), and

Received: June 05, 2017 Revised: June 11, 2017 Accepted: June 26, 2017

\footnotetext{
${ }^{\dagger}$ These authors contributed equally to this study. ${ }^{*}$ Corresponding author : Kwang-Young Song, Center for One Health, College of Veterinary Medicine, Konkuk University, Seoul, Korea. Tel : +82-2-450-4121, Fax : +82-2-3436-4128, E-mail : drkysong@gmail.com
} flaxseed was one of the oldest crops, having been cultivated since the beginning of civilization (Laux, 2011). Every part of the flaxseed plant was utilized commercially, either directly or after processing, while flaxseed oil and its sub-products were used in animal feed formulation (Laux, 2011; Singh et al., 2011; Shim et al., 2014) (Fig. 1).

There is a small difference in using the terms flaxseed (when consumed as food by humans) and linseed (when it was used in the industry and feed purpose) (Morris, 2008). Until now, flaxseed has been the focus of increased interest in the field of diet and disease research due to the potential health benefits associated with some of its biologically active components(Goyal et al., 2014; Shim et al., 2014) (Table 1).

This is an Open Access article distributed under the terms of the Creative Commons Attribution Non-Commercial License (http://creativecommons.org/ licenses/by-nc/3.0) which permits unrestricted non-commercial use, distribution, and reproduction in any medium, provided the original work is properly cited. 


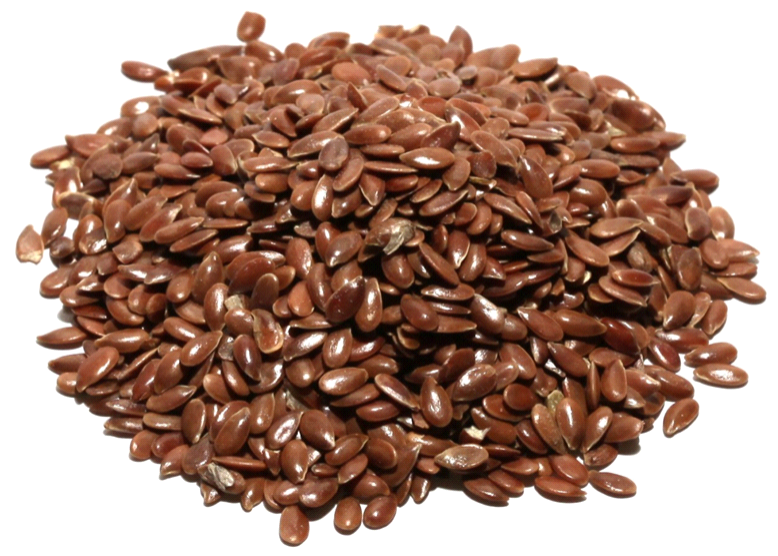

Fig. 1. Linum usitatissimum L. (flaxseed) was one of the oldest cultivated corps, continues to be widely grown for oil, fiber, and food (Resource: Shim et al., 2014).

Flaxseeds have nutritional characteristics and are rich source of $\omega^{-3}$ fatty acid, $\alpha$-linolenic acid (ALA), short chain polyunsaturated fatty acids (PUFA), soluble and insoluble fibers, phytoestrogenic lignans (secoisolariciresinol diglycoside-SDG), proteins and an array of antioxidants (Ivanova et al., 2011; Singh et al., 2011; Oomah, 2001; Alhassane and $\mathrm{Xu}, 2010)$.

And, according to various previous researches, flaxseed could have the health imparting benefits for reducing the

Table 1. Physiological effects imparted by functional elements of flaxseeds (Resource: Goyal et al., 2014; Shim et al., 2014)

\begin{tabular}{ll}
\hline \multicolumn{1}{c}{ Increase $(\uparrow)$} & \multicolumn{1}{c}{ Decrease $(\downarrow)$} \\
\hline 1. Apoptosis & 1. Angiogenesis \\
2. Bowel movement & 2. Blood pressure \\
3. Fluidity of cardiac muscles & 3. Blood viscosity \\
4. Glucose uptake & 4. Cardiac arrest \\
5. HLD-cholesterol & 5. LDL-oxidation \\
6. Peristalsis & 6. Level of pro-inflammatory \\
7. Production of 'memory boosting' & \multicolumn{1}{c}{ cytokines } \\
acetylcholine & 7. Morning stiffness \\
8. Production of anti-inflammatory & 8. Obesity \\
3-series eicosanoid compound & 9. Prostate \& colon cancer \\
9. Production of less aggregatory & 10. Reduce pain in joints \\
3-series eicosanoids compound & 11. Rheumatoid arthritis \\
10. Production of serotonin & 12. Serum glucose \\
11. Vasodilatory response & 13. Synthesis of VLDL \\
& 14. Total cholesterol \\
& 15. Triglyceride production \\
\hline
\end{tabular}

cardiovascular diseases, for decreasing the risk of cancer related to the mammary and prostate gland, for alleviating the menopausal symptoms and osteoporosis, for promoting the anti-inflammatory activity and laxative effect, and so on (Goyal et al., 2014). Above all, flaxseed was added to animal feed to improve animal reproductive performance and health (Heimbach, 2009; Turner et al., 2014). Generally, lactic acid bacteria (LAB) like generally recognized as safe (GRAS) was an order of Gram-positive, acidtolerant, nonsporulating, rod-(or coccus-) shaped bacteria that shared the physiological and metabolic characteristics. Usually found in decomposing plants and milk products, LAB produced lactic acid as the major metabolic end product of carbohydrate fermentation. Through the acidification's process by several LAB strains, it could be provide an additional hurdle for spoilage and pathogenic microorganisms, and hence contribute to the healthy microflora of human mucosal surfaces (Lee et al., 2014; Chatterjee et al., 2016). However, whether crude flaxseed extract have the growth stimulating effects of kefir-isolated lactic acid bacteria in vitro is not know.

Therefore, we assessed the effects of crude flaxseed extract on the growth of Kefir-isolated lactic acid bacteria and identified the main active compounds in crude flaxseed extract responsible for the growth-stimulating effects.

\section{Materials and Methods}

\section{Crude flaxseed extract from flaxseed (Linum usitati- ssimum L.)}

Flaxseed (Linum usitatissimum L.) was donated from Center for One Health, College of Veterinary Medicine, Konkuk University in Seoul, Korea. The dried flaxseed (Linum usitatissimum L.) was macerated in $100 \%$ sterilized distilled water for 48 hours with occasionally stirring at room temperature. And then, the soluble ingredients were concentrated were filtrated through $0.45 \mathrm{~mm}$ Millipore and stored at $-20^{\circ} \mathrm{C}$ before use.

\section{Preparation of 4 kefir-isolated lactic acid bacteria} As probiotic cultrure, 4 Kefir-isolated lactic acid bacteria 
tested in this study were originated from Kefir, and donated from Center for One Health, College of Veterinary Medicine, Konkuk University in Seoul, Korea, Lactobacillus kefiranofaciens DN1, Lactobacilllus brevis KCTC3102, Lactobacillus bulgaricus KCTC3635, and Lactobacillus plantarum KCTC3105. All 4 kefir-isolated lactic acid bacteria were grown in MRS broth and were incubated at $37^{\circ} \mathrm{C}$ for 48 hrs.

\section{Effect of crude flaxseed extract on the growth of various Kefir-isolated lactic acid bacteria}

The effect of crude flaxseed extract on the growth of various Kefir-isolated lactic acid bacteria was determined with growth curve analysis. A total of $100 \mu \mathrm{L}$ crude flaxseed extract was added to $1 \mathrm{~mL}$ of MRS broth, and also inoculated with $50 \mu \mathrm{L}$ suspensions of each Kefir-isolated lactic acid bacteria at the level of $10^{5}$ Log CFU. After mixing and incubating at $37^{\circ} \mathrm{C}$, optical density was measured at $600 \mathrm{~nm}$ at $1 \mathrm{~h}$ intervals using a microplate reader (Multiskan FC; Thermo Fisher Scientific, Waltham, MA, USA).

\section{Statistical analysis}

All data were presented as mean \pm SD (standard deviation), and were the results of at least two independent experiments with duplicate assays. All statistical analysis were performed using one-way analysis of variance (ANOVA; GraphPad Prism 5, USA) followed by Duncan's post hoc test for mean comparison. Statistical significance was established as $p<0.05$.

\section{Results and Discussion}

In this study, the growth of 4 kefir-isolated lactic acid bacteria in MRS broth containing 10\% final volumes (100 $\mu \mathrm{L} / 1 \mathrm{~mL}$ ) of crude flaxseed extract from flaxseed (Linum usitatissimum L.) was analyzed by measuring the optical density of cultures at $600 \mathrm{~nm}$ (Fig. 2). This results of this study showed that Lactobacillus kefiranofaciens DN1, Lactobacilllus brevis KCTC3102, Lactobacillus bulgaricus KCTC3635, and Lactobacillus plantarum KCTC3105 with the addition of $100 \mu \mathrm{L}$ crude flaxseed extract from flaxseed
(Linum usitatissimum L.) showed higher stimulation than control with addition of $100 \mu \mathrm{L}$ water (Fig. 2). There was a significant difference between treated group with the addition of crude flaxseed extract from flaxseed (Linum usitatissimum L.) and control group $(p<0.05)$.

As shown in Fig. 2, Lactobacillus kefiranofaciens DN1 with the addition of $100 \mu \mathrm{L}$ crude flaxseed extract from flaxseed (Linum usitatissimum L.) showed the significant growth-stimulation from 14 hours to 24 hours $(p<0.05)$, Lactobacilllus brevis KCTC3102 and Lactobacillus plantarum KCTC3105 with the addition of $100 \mu \mathrm{L}$ crude flaxseed extract from flaxseed (Linum usitatissimum L.) showed the significant growth-stimulation from 17 hours to 24 hours and from 18 hours to 24 hours, respectively $(p<0.05)$. And Lactobacillus bulgaricus KCTC3635 with the addition of $100 \mu \mathrm{L}$ crude flaxseed extract from flaxseed (Linum usitatissimum L.) showed the significant growth-stimulation from 14 hours to 21 hours. However, Lactobacillus bulgaricus KCTC3635 without the addition of $100 \mu \mathrm{L}$ water showed the significant stimulation from 23 hours to 24 hours $(p<0.05)$, maybe it was thought to be due to $\mathrm{pH}$. Until now, several bifidogenic (or lactic acid bacteria) growth stimulators have been reported such as 2-amino3-carboxy-1,4-naphthoquinone, 1,4-dihydroxy-2-naphthoic acid, O- $\alpha$-d-Glucopyranosyl-( $1 \rightarrow 6)-\mathrm{O}-\alpha$-d-glucopyranosyl$(1 \rightarrow 4)-\alpha-d-$ glucose, and so on (Isawa et al., 2002; Makelainen et al., 2009).

Lee et al. (2014) reported that fermented rice extract (0.2\%) stimulated the growth of the lactic acid bacteria such as Lactobacillus acidophilus, Streptococcus thermophilus, and Bifidobacterium lactis. Specifically, the number of bacteria increased significantly to 11 53 fold after 12-18 hours incubation, compared with negative control significant $(p<0.05)$. Namely, fermented rice extract with known or unknown substances strongly stimulated the growth of both bifidobacteria and lactic acid bacteria. Also, Chatterjee et al. (2016) studies the growth of lactic acid bacteria using fruit pectin. Pectin could be classified as a prebiotic on food ingredient. Generally, however, it is assumed that a prebiotic should increase the number or activity of bifidobacteria and lactic acid bacteria (Gibson 

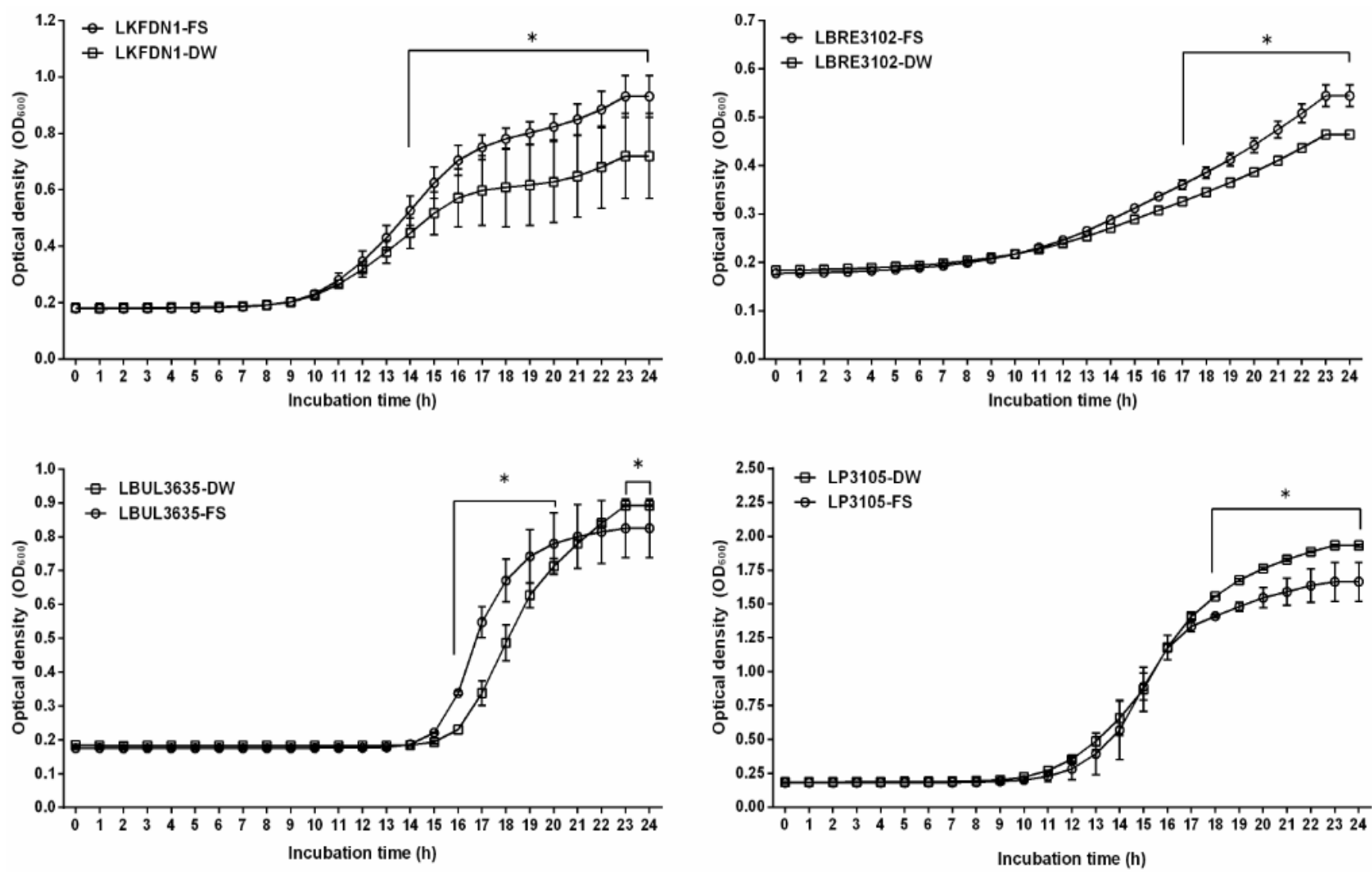

Fig. 2. Growth curves of Lactobacillus kefiranofaciens DN1, Lactobacillus brevis KCTC3102, Lactobacillus bulgaricus KCTC3635, and Lactobacillus plantarum KCTC3105 as kefir-isolated lactic acid bacteria grown in MRS broth mixed with crude flaxseed extract from flaxseed (Linum usitatissimum L.) at $10 \%$ final concentration at $37^{\circ} \mathrm{C}$ for $24 \mathrm{~h}$. Growth was analyzed by measuring optical density at $600 \mathrm{~nm}$.

and Collins, 1999). According to research results of Chatterjee et al. (2016), the optical density was measured at $660 \mathrm{~nm}$, for Lactobacillus acidophilus culture it was found to be 0.8 at 48 hrs of incubation and 0.77 by 60 hrs of incubation at $37^{\circ} \mathrm{C}$. Whereas Bifidobacterium bifidum O.D. value was 0.6 at 48 hrs and 0.56 at 60 hrs of incubation. There was no significant change in the growth of lactic acid bacteria on incubation for 60 hrs, Lactobacillus casei the OD was 1.004 at 48 hrs and 0.985 at 60 hrs. There was a reduction in the absorbance when the cultures were incubated more than 48 hrs. Especially, the $\mathrm{pH}$ at which the fermentation was carried out had a direct effect on the substrate metabolism due to the change in enzyme activity at different $\mathrm{pH}$ (Palframan et al., 2002). According to the results of this study, crude flaxseed extract from flaxseed (Linum usitatissimum L.) could be a potential prebiotic so as to stimulate the bacteria to grow on colon and then alter the colonic microflora toward a more health composition. Further understanding of the protective mechanisms conferred by crude flaxseed extract from flaxseed (Linum usitatissimum L.) will further enhance the numerous beneficial effects of prebiotics. The results of the current study suggest that crude flaxseed extract from flaxseed (Linum usitatissimum L.) could be used as the growth-stimulating agents for Kefir-isolated lactic acid bacteria.

\section{Disclaimer}

The views expressed herein do not necessarily reflect those of the US Food and Drug Administration or the US Department of Health and Human Services. 


\section{References}

1. Alhassane, T., Xu, X. M. 2010. Flaxseed lignans: source, biosynthesis, metabolism, antioxidant activity, bio-active components and health benefits. Compr. Rev. Food Sci. Food Saf. 9:261-269.

2. Chatterjee, E., Manuel, S. G. A. and Hassan, S. S. 2016. Effect of fruit pectin on growth of lactic acid bacteria. J. Probiotics \& Health, 4:147.

3. Gibson, G. R. and Collins, M. D. 1999. Concept of balanced colonic microbiota, prebiotics and synbiotics. In: Hanson, L. A., Yolken, R. H. (eds). Probiotics Other Nutritional Factors, and Intestinal Microflora 42: 139-152.

4. Goyal, A., Sharma, V., Upadhyay, N., Gill, S. and Sihag, M. 2014. Flax and flaxseed oil: an ancient medicine \& modern functional food. J. Food Sci. Technol. 51:1633-1653.

5. Isawa, K., Hojo, K., Yoda, N., Kamiyama, T., Makino, S., Saito, M., Sugano, H., Mizoguchi, C., Kurama, S., Shibasaki, M., Endo, N. and Sato, Y. 2002. Isolation and identification of a new bifidogenic growth stimulator produce by Propionibacterium freudenreichii ET-3. Biosci. Biotechnol. Biochem. 66:679-681.

6. Ivanova, S., Rashevskaya, T. and Makhonina, M. 2011. Flaxseed additive application in dairy products production. Procedia. Food Sci. 1:275-280.

7. Kaithwas, G., Mukerjee, A., Kumar, P. and Majumdar, D. K. 2011. Linum usitatissimum (linseed/flaxseed) fixed oil: Antimicrobial activity and efficacy in bovine mastitis. Inflammopharmacology 19:45-52.

8. Laux, M. 2011. http://www.agmrc.org/commodities_ products/grains_oilseeds/flax_profile.cfm. Accessed May
10, 2017.

9. Lee, J. K., Cho, H. R., Kim, K. Y., Lim, J. M., Jung, G. W., Sohn, J. H. and Choi, J. S. 2014. The growthstimulating effects of fermented rice extract (FRe) on lactic acid bacteria and Bifidobacterium spp. Food Science and Technology Research 20:479-483.

10. Makelainen, H., Hasselwander, O., Rautonen, N. and Ouwehand, A. C. 2009. Panose, a new prebiotic candidate. Lett. Appl. Microbiol. 49:666-672.

11. Morris, D. H. 2008. Linseed in the ruminant diet adding linseed to feed enhances the fat profile of milk Winnipeg, MB, Flax Council of Canada. http://www. flaxcouncil.ca/files/web/Beef_R3_final.pdf. Accessed May 15, 2017.

12. Oomah, B. D. 2001. Flaxseed as a functional food source. J. Sci. Food Agric. 81(9):889-894.

13. Palframan, R. J., Gibson, G. R. and Rastall, R. A. 2002. Effect of $\mathrm{pH}$ and dose on the growth of gut bacteria on prebiotic carbohydrates in vitro. Anaerobe 8:287292.

14. Shim, Y. Y., Gui, B., Arnison, P. G., Wang, Y., and Reaney, M. J. T. 2014. Flaxseed (Linum usitatissimum L.) bioactive compounds and peptide nomenclature: A review. Trends in Food Science \& Technology 38:5-20.

15. Singh, K. K., Mridula, D., Rehal, J. and Barnwal, P. 2011. Flaxseed- a potential source of food, feed and fiber. Crit. Rev. Food Sci. Nutr. 51:210-222.

16. Turner, T. D., Mapiye, C., Aalhus, J. L., Beaulieu, A. D., Patience, J. F., Zijlstra, R. T. and Dugan, M. E. 2014. Flaxseed fed port: n-3 fatty acid enrichment and contribution to dietary recommendations. Meat Science 96:541-547. 